\title{
Fingerprinting and Identification of Bacteria Present in UASB Granules Used to Treat Winery, Brewery, Distillery or Peach-lye Canning Wastewater
}

\author{
M. Keyser, T.J. Britz and R.C. Witthuhn* \\ Department of Food Science, Stellenbosch University, Private Bag X1, Matieland 7602, South Africa \\ Submitted for publication: February 2007 \\ Accepted for publication: April 2007 \\ Key words: fingerprinting and identification; microbial consortium; PCR-based DGGE; UASB; wastewaters
}

\begin{abstract}
The effective operation of the anaerobic digestion process in an upflow anaerobic sludge blanket (UASB) bioreactor is dependent on the microbial composition of the UASB granules. The granules contain a consortium of bacteria, with a specific metabolic function for each group, contributing to the overall efficiency and stability of the bioreactor. The aim of this study was to fingerprint and identify the bacteria present in four different types of South African UASB granules that are used to treat winery, brewery, distillery and peach-lye canning wastewaters. This was done by combining conventional microbiological platings with PCR-based denaturing gradient gel electrophoresis (DGGE) and DNA sequence analysis. Each granule type showed distinct PCR-based DGGE fingerprints with unique bands, while other bands were found to be present in all the granules, regardless of the wastewater being treated. Sixty-eight different bacteria (40 pure isolates and 28 clones) were partially sequenced and identified from the winery, brewery, distillery and peach-lye canning granules. Thirty-five percent of the identified bacteria represented the unculturable bacteria and $65 \%$ represented the culturable bacteria, which included members of the following genera: Bacillus, Pseudomonas, Bacteroides, Enterococcus, Alcaligenes, Clostridium, Shewanella, Microbacterium, Leuconostoc, Sulfurospirillum, Acidaminococcus, Vibrio, Aeromonas, Nitrospira, Synergistes, Rhodococcus, Rhodocyclus and Syntrophobacter. A DGGE marker was successfully constructed, representing members of the bacterial consortium in UASB granules.
\end{abstract}

\section{INTRODUCTION}

The upflow anaerobic sludge blanket (UASB) process has been widely used for the biological treatment of wastewaters from food and beverage processing (Wolmarans and De Villiers, 2002). These types of wastewaters normally have a high organic content and contain little or no toxic solids, providing the ideal conditions for bioreactor operation (Trnovec and Britz, 1998). The efficiency and stability of UASB bioreactors are dependent on the microbial composition of wastewaters (Roest et al., 2005). The microorganisms present in the seeding sludge form dense aggregates or granules through a granulation process characteristic of these bioreactors. The granules that are formed consist of different trophic groups, which are necessary for anaerobic digestion (Sekiguchi et al., 1998). These are the acidogenic, acetogenic, homoacetogenic and methanogenic bacteria. These microbial groups are responsible for executing the consecutive stages of the anaerobic digestion process, where the metabolic products of one microbial group are assimilated by the next microbial group (Gerardi, 2003).

Acidogens are responsible for the degradation of organic material to form carbon dioxide, hydrogen, acids and alcohols
(Wangnai et al., 2004). The acetogenic bacteria convert the fatty acids to acetic acid and hydrogen (Van Andel and Breure, 1984). To prevent hydrogen accumulation, the homoacetogenic bacteria utilise carbon dioxide and hydrogen to form acetate as an endproduct. The methanogens convert the acetate and hydrogen to methane and carbon dioxide (Batstone et al., 2002). Variations in the composition of one trophic group as a result of changes in substrate composition, reactor temperature, retention time and even $\mathrm{pH}$ may influence the entire microbial community structure (Casserly and Erijman, 2003). It is, therefore, important to identify the bacteria present in each granule type so as to better understand and optimise the metabolic activity of the different trophic groups present in the different granules, which will result in the successful operation of a UASB bioreactor.

When treated, different types of wastewaters also have an influence on the microbial consortium present in the granules. Keyser et al. (2006) analysed different UASB granules and showed that different methanogenic bacteria were present in the different types. Each type of wastewater favours the growth of specific bacteria that may have an impact on the success of the granulation process and, subsequently, on the successful operation of the 
UASB bioreactor. Each type of bacteria present in the granules performs a specific metabolic role in the granules, and contributes to their performance and ultimately that of the UASB bioreactor. Thus, it is essential to identify the various microorganisms in a bioreactor, since they play a role in its successful operation.

The use of conventional culture-dependent methods to isolate microorganisms from the UASB environment is limited due to the inability of many microorganisms to grow on synthetic media. Over the past few years, culture-independent methods therefore have proven to be of value for the identification of bacteria in complex samples (Roest et al., 2005). The aim of this study was firstly to use sequence analysis to identify the mixed microbial community, comprising different culturable and unculturable bacteria, that are present in four different types of UASB granules that had been used to treat either winery, brewery, distillery or peach-lye canning wastewaters. Secondly, PCR-based DGGE was used to obtain the unique fingerprint for each of the granule types in order to construct a DGGE marker representing some of the identified bacteria present in the four different UASB granule types so as to facilitate future rapid identification of UASB microorganisms.

\section{MATERIALS AND METHODS}

The PCR-based DGGE analysis used in this study was based on the amplification of a 200 base pair (bp) PCR product using the primers F341 with GC-clamp and R534 (Muyzer et al., 1993). DGGE profiles (200 bp) were obtained from the DNA isolated from the four different UASB granules. In addition, 1.5 kilobase (kb) fragments were amplified from the DNA of the different granules using the primers F8 and R1512 (Felske et al., 1997), and these were cloned and sequenced to enable identification. In order to confirm that all the microorganisms in the $200 \mathrm{bp}$ DGGE profile had been cloned, sequenced and identified (using the 1.5 $\mathrm{kb}$ fragment), a $200 \mathrm{bp}$ PCR fragment was amplified from the 1.5 $\mathrm{kb}$ PCR products. The resulting DGGE profile was compared to that of the profile obtained directly from the DNA of the different granules.

Identification of the culturable microorganisms was achieved by obtaining pure isolates from the different UASB granules using microbial platings. DNA was isolated from these pure isolates and a $1.5 \mathrm{~kb}$ fragment was amplified and sequenced in order to identify the culturable microorganisms. The DNA from these isolates was also amplified (200 bp), separated using DGGE and compared to the DGGE profiles of the different UASB granules. A DGGE marker was constructed to represent the microorganisms identified from the different UASB granules.

\section{UASB granules}

Three of the different types of UASB granules were obtained in $20 \mathrm{~kg}$ batches from available and operational industrial-scale UASB bioreactors in South Africa. The granule batches that had been used in the treatment of winery and distillery wastewaters were obtained from Distell, Stellenbosch, Western Cape, RSA. The brewery granules were obtained from the SAB brewery plant in Amanzimtoti, Kwazulu-Natal, RSA. The fourth granule type was originally from the full-scale SAB brewery UASB bioreactor, but had then been used as inoculum for a $60 \mathrm{~L}$ laboratoryscale UASB bioreactor treating peach-lye canning wastewater at the Department of Food Science, Stellenbosch University. This
60 L UASB bioreactor was operated for 15 months on the peachlye canning effluent before granules were taken for analysis.

\section{Microbial isolations}

Randomly selected granules from each of the four different types of UASB granules were homogenised with a sterile pestle in $9 \mathrm{~mL}$ of sterile saline solution $(0.85 \%(\mathrm{~m} / \mathrm{v}) \mathrm{NaCl})$ and a dilution series $\left(10^{-1}\right.$ to $\left.10^{-8}\right)$ was prepared. Each dilution was plated on nutrient agar (NA) (Biolab, supplied by Merck, Cape Town, South Africa) and on deMan, Rogosa and Sharpe agar (MRS) (Biolab, supplied by Merck, Cape Town, South Africa). The plates were incubated aerobically and anaerobically at $35^{\circ} \mathrm{C}$ for two days using the Anaerocult A system (Merck, Cape Town, South Africa). Although MRS is selective for lactic acid bacteria, it facilitates the growth of many bacteria (Van der Merwe and Britz, 1994). All the bacterial colonies obtained were streaked until pure isolates were obtained. The pure isolates were Gram-stained and microscopically examined to confirm isolate purification. These pure isolates were subjected to PCR amplification, purification and sequencing.

\section{Genomic DNA extraction}

DNA was extracted from the four different types of UASB bioreactor granules using the method of Van Elsas et al. (1997) as modified by Keyser et al. (2006). All the DNA extractions were done in duplicate.

\section{PCR-based DGGE analysis}

\section{PCR amplifications}

PCR reactions were performed using the primers F341 (5' CC TAC GGG AGG CAG CAG 3') with GC-clamp (5' CGC CCG CCG CGC GCG GCG GGC GGG GCG GGG GCA CGG GGG G 3') and R534 (5' ATT ACC GCG GCT GCT GG 3'), as described by Muyzer et al. (1993). The primers amplify approximately 200 base pairs (bp) of the V3 variable region within the 16S ribosomal RNA (rRNA) gene (corresponding to positions 341 to 534 of the $16 \mathrm{~S}$ rRNA gene of Escherichia coli). PCR reactions and conditions are as described by Keyser et al. (2006), using $1 \mu \mathrm{l} 99 \%$ (v/v) dimethyl sulphoxide (DMSO) (Merck, Cape Town, South Africa) instead of bovine serum albumin (BSA).

In order to obtain sufficient DNA sequences to identify the bacteria present, a $1.5 \mathrm{~kb}$ fragment of the 5' end of the $16 \mathrm{~S}$ rRNA gene was amplified from the different granule DNA using the primers F8 (5' CAC GGA TCC AGA CTT TGA TYM TGG CTC AG 3') and R1512 (5' GTG AAG CTT ACG GYT AGC TTG TTA CGA CTT 3') (Felske et al., 1997). PCR reactions were performed in $50 \mu \mathrm{l}$ reaction volumes, containing $1 \mu \mathrm{l} \mathrm{Taq}$ DNA polymerase $(5 \mathrm{U} / \mu \mathrm{l})$ (Promega), $5 \mu \mathrm{l} 10 \times$ PCR reaction buffer, $2 \mu \mathrm{l}$ of each of the primers $(10 \mu \mathrm{l}), 2 \mu \mathrm{l}$ dNTPs $(10 \mathrm{mM})$ (Promega), $2 \mu \mathrm{l} 99 \%(\mathrm{v} / \mathrm{v})$ DMSO (Merck, Cape Town, South Africa) and $2 \mu \mathrm{l}$ of the extracted DNA $\left(\sim 30 \mathrm{ng} \cdot \mu \mathrm{l}^{-1}\right)$. The PCR amplification conditions were as follows: initial denaturation was at $92^{\circ} \mathrm{C}$ for $3 \mathrm{~min}$; followed by denaturation at $92^{\circ} \mathrm{C}$ for $30 \mathrm{sec}$; primer annealing at $54^{\circ} \mathrm{C}$ for 30 sec; and chain elongation at $68^{\circ} \mathrm{C}$ for $1 \mathrm{~min}$. These three steps were repeated for 35 cycles. Final chain elongation was performed at $72^{\circ} \mathrm{C}$ for $7 \mathrm{~min}$ (Felske et al., 1997). All the amplified PCR products were separated on $1 \%(\mathrm{~m} / \mathrm{v})$ agarose gels containing ethidium bromide and visualised under UV light (Vilber Lourmat).

A PCR reaction amplifying a $200 \mathrm{bp}$ part of the 5' end of the $16 \mathrm{~S}$ rRNA gene was performed on the amplified $1.5 \mathrm{~kb}$ PCR frag- 
ments, using the primers F341 and R534 (Muyzer et al., 1993). This was done to confirm that each $200 \mathrm{bp}$ band in the DGGE fingerprints was represented by a $1.5 \mathrm{~kb}$ PCR product that was sequenced.

\section{DGGE}

The 200 bp PCR fragments were separated using DGGE, performed with the BioRad DCode ${ }^{\mathrm{TM}}$ Universal Mutation Detection System (BioRad Laboratories, USA). The PCR products were applied to $8 \%(\mathrm{~m} / \mathrm{v})$ polyacrylamide gels with a gradient of between 45 and $70 \%$ (containing 0 to $100 \%$ denaturant (7M urea and $40 \%$ (v/v) formamide)) as described by Keyser et al. (2006).

\section{Cloning}

The $1.5 \mathrm{~kb}$ PCR fragments obtained from the amplification of the DNA extracted from the different granules were cloned into the pGemT-Easy Vector System II (Promega), since the PCR product contained a mixture of fragments with different DNA sequences. All the transformed cells were screened for the correctly sized insert using the primers T7 and SP6. Amplification reactions were performed in a total reaction volume of $50 \mu \mathrm{l}$, containing $1 \mu \mathrm{l} \mathrm{Taq}$ DNA polymerase $(5 \mathrm{U} / \mu \mathrm{l})$ (Roche Diagnostics), $5 \mu \mathrm{l} 10 \mathrm{x}$ PCR buffer, $2 \mu \mathrm{l}$ of each of the primers $(10 \mu \mathrm{M})$ and $2 \mu \mathrm{l}$ dNTPs $(10$ $\mathrm{mM}$ ) (Promega). The PCR amplification conditions consisted of an initial denaturation at $92^{\circ} \mathrm{C}$ for $3 \mathrm{~min}$, followed by 35 cycles of denaturation at $92^{\circ} \mathrm{C}$ for $30 \mathrm{sec}$, annealing at $54^{\circ} \mathrm{C}$ for $30 \mathrm{sec}$, elongation at $68^{\circ} \mathrm{C}$ for $1 \mathrm{~min}$, and a final $7 \mathrm{~min}$ elongation at $72^{\circ} \mathrm{C}$.

\section{PCR purification}

All the amplified $1.5 \mathrm{~kb}$ PCR fragments that were sequenced were purified using the High Pure PCR Product Purification Kit (Roche Diagnostics) according to the manufacturer's instructions.

\section{DNA sequencing}

All the obtained and purified $1.5 \mathrm{~kb}$ PCR fragments were sequenced using the ABI PRISM 377 DNA Sequencer (PerkinElmer) at the DNA Sequencing Facility at Stellenbosch University. The sequences obtained were compared to 16S rRNA gene sequences available in the National Centre for Biotechnology Information (NCBI) database using the BLASTn search option (Altschul et al., 1990).

\section{Phylogenetic analysis}

The 16S rRNA gene sequences were manually aligned by inserting gaps and the phylogenetic analyses were conducted using MEGA 2.1 (Kumar et al., 2001). The percentage similarities were calculated to identify the species.

\section{DGGE marker}

Eighteen DGGE bands were selected from the profiles obtained for the different granules. These bands represented cloned PCR fragments, as well as isolates from the different granules. The PCR products of the selected DGGE bands were separated using DGGE by loading $2 \mu \mathrm{l}$ of each reaction mixture in the same well.

\section{RESULTS AND DISCUSSION}

\section{PCR-based DGGE fingerprinting of the different UASB granules}

The initial 200 bp PCR amplification products that were obtained were successfully separated using DGGE to produce unique fingerprints for each of the granule types evaluated. PCR-based DGGE fingerprints of duplicate DNA extractions of each granule type were found, as shown in Figure $1 \mathrm{~A}$ and B, to be reproducible. Distinct fingerprints, containing unique bands, were observed for the four different UASB granules.

Definite bands were in the same position on the gel and present in all the granules, suggesting that a section of the microbial composition, under the conditions employed in this study, was identical and constant, irrespective of the wastewater being treated (Figure 1A and B). This suggests that the organisms represented by those bands are constant, irrespective of the wastewater being treated.

Certain bands in the fingerprints from the peach-lye canning granules were similar to bands found in the fingerprints of the brewery granules. Other bands present in the fingerprints of the peach-lye canning granules were not observed in the fingerprints of the brewery granules. These similarities and differences between the peach-lye canning and brewery granules are clear indications of changes in the microbial consortium when granules are subjected to a change in wastewater composition. This confirms that the composition of the wastewater being treated has an impact on the microbial species present in the granules.

\section{Species identification}

Sixty-eight different bacteria (40 pure cultured isolates and 28 clones) were identified from the winery, brewery, distillery and peach-lye canning granules. Of the 68 bacteria, 24 were representative of uncultured bacteria, constituting $35 \%$ of the identified bacteria. The remaining $65 \%$ were culturable bacteria. In Table 1, a summary is provided of the number given to each unique DGGE band, whether it was identified from cloned PCR fragments or pure isolates (cultured bacteria), the number of bases of each fragment sequenced and its GenBank accession number, as well as the closest relative and the percentage sequence similarity.

Certain bacteria were specific to a certain granule type, while other bacteria were found to be present in more than one granule. Clostridium was only identified in the distillery granules, while Enterococcus, Leuconostoc, Aeromonas, Vibrio and species related to Rhodocyclus, Nitrospira, Rhodococcus and Syntrophobacter were present only in the brewery granules. Microbacterium species were found only in the winery granules. Sulfurospirillum and species related to Acidaminococcus were found only in the peach-lye canning effluent granules. The most identified species of bacteria present in all four granule types were species of Bacillus and Pseudomonas. A total of 20 Bacillus and 14 Pseudomonas were identified in the various granules used in this study.

\section{Bacillus:}

Nineteen members of the genus Bacillus were found to be present in four different UASB granule types. Seven of these were present in the winery granules, five in the distillery granules, four in the peach-lye canning granules and three in the brewery granules. A comparative analysis was done of the sequences retrieved from GenBank and the percentage similarity can be observed in Table 1. Band W10 showed a 99.2\% sequence similarity to an unidentified bacterium (Accession number AY345491) (Table 1) previously isolated from a sediment sample and all the other bands were found to be closely related to B. cereus. Band PL4 was 
TABLE 1

Identification of bacteria present in different UASB granules.

\begin{tabular}{|c|c|c|c|c|c|}
\hline $\begin{array}{l}\text { DGGE band } \\
\text { I - Isolate } \\
\text { C - Clone }\end{array}$ & $\begin{array}{l}\text { Sequence } \\
\text { length } \\
\text { (bp) }\end{array}$ & $\begin{array}{l}\text { GenBank } \\
\text { accession number } \\
\text { (clone/isolate) }\end{array}$ & $\begin{array}{l}\text { \% Sequence } \\
\text { similarity }\end{array}$ & Closest relative & $\begin{array}{l}\text { GenBank accession } \\
\text { number } \\
\text { (closest relative) }\end{array}$ \\
\hline \multicolumn{6}{|l|}{ Bacillus } \\
\hline $\mathrm{W} 1-\mathrm{I}$ & 510 & DQ238239 & 99.6 & Bacillus pycnus sp. NRS-1695 & AF169535 \\
\hline $\mathrm{W} 2-\mathrm{I}$ & 510 & DQ238238 & 99.8 & Bacillus megaterium KL-197 & AY030338 \\
\hline W3 - I & 506 & DQ238244 & 98.2 & Bacillus sp. TKSP21 & AF411341 \\
\hline W6 - I & 511 & DQ238240 & 100 & Bacillus cereus G9667 & AY138273 \\
\hline W9- I & 511 & DQ238242 & 100 & Bacillus cereus $\mathrm{J}-1$ & AY305275 \\
\hline W10 - I & 510 & DQ238243 & 99.2 & Unidentified bacterium clone W4B-B03 & AY345491 \\
\hline W20 - I & 511 & DQ238241 & 100 & Bacillus subtilis ATCC21331 & AB018487 \\
\hline B6 - I & 511 & DQ238237 & 100 & Bacillus cereus $\mathrm{J}-1$ & AY305275 \\
\hline B7 - I & 510 & DQ239796 & 100 & Bacillus fusiformis DSM2898T & AJ310083 \\
\hline B12 - I & 510 & DQ238236 & 96.5 & Bacillus sphaericus PLC-5 & AY161044 \\
\hline D1 - I & 511 & DQ238249 & 100 & Bacillus cereus $\mathrm{B} 412$ & AJ577281 \\
\hline D2 - I & 511 & DQ238248 & 100 & Bacillus subtilis KL-077 & AY030331 \\
\hline D3 - I & 491 & DQ238247 & 99.8 & Bacillus sp. 19497 & AJ315065 \\
\hline D5 - I & 511 & DQ238246 & 100 & Bacillus subtilis $\mathrm{C} 15$ & AF274248 \\
\hline D16 - I & 511 & DQ238251 & 100 & Bacillus cereus RIVM BC00068 & AJ577283 \\
\hline PL2 - I & 511 & DQ238255 & 100 & Bacillus cereus ATCC535221 & AF290551 \\
\hline PL3 - I & 511 & DQ238254 & 100 & Bacillus sp. A24 & AF397399 \\
\hline PL4 - I & 508 & DQ238253 & 99.6 & Bacillus pumilus & AF393657 \\
\hline PL6 - I & 511 & DQ238256 & 100 & Bacillus sp. TKSP21 & $\mathrm{AB} 017591$ \\
\hline \multicolumn{6}{|l|}{ Pseudomonas } \\
\hline B4 - I & 682 & DQ238235 & 99.9 & Brevundimonas bullata & AB023428 \\
\hline D4 - I & 739 & DQ238233 & 98.1 & Sulphide-oxidizing bacterium N9-1 & AF393509 \\
\hline D6 - I & 731 & DQ238232 & 97.8 & Pseudomonas sp. AMSN & AF438148 \\
\hline $\mathrm{D} 10-\mathrm{C}$ & 729 & DQ238270 & 94.7 & Burkholderia pyrrocinia strain R13058 & AJ440714 \\
\hline $\mathrm{D} 13-\mathrm{C}$ & 730 & DQ238271 & 98.5 & Pseudomonas sp. NZ112 & AY014826 \\
\hline PL1 - I & 736 & DQ238231 & 99.2 & Pseudomonas fluorescens & AF094726 \\
\hline \multicolumn{6}{|l|}{ Pseudomonas } \\
\hline PL5 - I & 732 & DQ238230 & 99.2 & Pseudomonas fluorescens bv. C & AF228367 \\
\hline PL8 - I & 736 & DQ238234 & 96.0 & Pseudomonas sp. 7-1 & AF521651 \\
\hline PL11 - C & 734 & DQ238263 & 99.6 & Uncultured Gamma Proteobacterium & $\mathrm{AB} 015570$ \\
\hline PL14 - C & 729 & DQ238262 & 99.6 & Pseudomonas veronii & AF064460 \\
\hline PL17 - C & 733 & DQ238260 & 99.3 & Pseudomonas sp. NZ024 & AY014806 \\
\hline PL19 - C & 736 & DQ238264 & 97.8 & Uncultured bacterium KM94 & AY216460 \\
\hline PL20 - C & 734 & DQ238259 & 99.6 & Pseudomonas putida & D85999 \\
\hline PL22 - C & 732 & DQ238261 & 98.4 & Pseudomonas viridiflava & AF364097 \\
\hline \multicolumn{6}{|l|}{ Bacteroides } \\
\hline W19-C & 886 & DQ238265 & 99.9 & Uncultured bacterium clone IIB-29 & AJ488088 \\
\hline D9 - C & 886 & DQ238269 & 99.3 & Uncultured bacterium clone IIIB-28 & AJ488099 \\
\hline $\mathrm{D} 15-\mathrm{C}$ & 886 & DQ238268 & 99.9 & Uncultured bacterium clone IIB-29 & AJ488088 \\
\hline PL16 - C & 885 & DQ238258 & 81.9 & Uncultured Bacteroidetes clone ML635J-40 & AF507859 \\
\hline \multicolumn{6}{|l|}{ Enterococcus } \\
\hline B1 - I & 738 & DQ238227 & 96.8 & Uncultured bacterium clone P-1938-s962-3 & AF371532 \\
\hline B11 - I & 737 & DQ238229 & 98.1 & Enterococcus sp. ALE-1 & AY017051 \\
\hline B13 - I & 740 & DQ238228 & 98.1 & Enterococcus durans & Y18359 \\
\hline \multicolumn{6}{|l|}{ Alcaligenes } \\
\hline W7 - I & 841 & DQ238224 & 99.8 & Achromobacter spanius & AY170848 \\
\hline B2 - I & 855 & DQ238226 & 93.6 & Uncultured bacterium clone ZZ14AC10 & AY214198 \\
\hline B3 - I & 848 & DQ238225 & 99.8 & Alcaligenes faecalis & AF155147 \\
\hline \multicolumn{6}{|l|}{ Clostridium } \\
\hline D7 - I & 894 & DQ191233 & 98.0 & Clostridium butyricum strain VPI3266 & AJ458420 \\
\hline D8 - I & 873 & DQ191234 & 97.2 & Clostridium bifermentans & AF320283 \\
\hline \multicolumn{6}{|l|}{ Shewanella } \\
\hline W8 - I & 626 & DQ191239 & 99.5 & Shewanella putrefaciens & U91551 \\
\hline B8 - I & 628 & DQ191238 & 91.2 & Shewanella putrefaciens & U91553 \\
\hline \multicolumn{6}{|l|}{ Microbacterium } \\
\hline W4 - I & 746 & DQ191236 & 99.5 & Microbacterium sp. PRLIST4 & Y15325 \\
\hline W5 - I & 742 & DQ191237 & 100 & Microbacterium oxydans & Y17227 \\
\hline \multicolumn{6}{|l|}{ Leuconostoc } \\
\hline B14 - I & 659 & DQ191235 & 85.1 & Uncultured Leuconostoc sp. clone LabS38 & AF335916 \\
\hline \multicolumn{6}{|c|}{ Sulfurospirillum } \\
\hline PL12 - C & 577 & DQ191240 & 98.9 & Sulfurospirillum arsenophilum & U85964 \\
\hline PL13 - C & 569 & DQ191241 & 98.1 & Sulfurospirillum halorespirans & AF218076 \\
\hline
\end{tabular}


TABLE 1 (continued)

Identification of bacteria present in different UASB granules.

\begin{tabular}{|c|c|c|c|c|c|}
\hline $\begin{array}{l}\text { DGGE band } \\
\text { I - Isolate } \\
\text { C - Clone }\end{array}$ & $\begin{array}{l}\text { Sequence } \\
\text { length } \\
\text { (bp) }\end{array}$ & $\begin{array}{l}\text { GenBank } \\
\text { accession number } \\
\text { (clone/isolate) }\end{array}$ & $\begin{array}{l}\text { \% Sequence } \\
\text { similarity }\end{array}$ & Closest relative & $\begin{array}{l}\text { GenBank accession } \\
\text { number } \\
\text { (closest relative) }\end{array}$ \\
\hline PL9 - C & 640 & DQ191232 & 91.8 & Unidentified eubacterium clone vadinHB04 & U81750 \\
\hline PL21 - C & 639 & DQ191231 & 94.8 & Uncultured bacterium clone ER1_17 & AY231317 \\
\hline \multicolumn{6}{|l|}{ Vibrio } \\
\hline B9 - I & 852 & DQ191248 & 99.9 & Vibrio parahaemolyticus & AY245192 \\
\hline \multicolumn{6}{|c|}{ Syntrophobacter } \\
\hline \multicolumn{6}{|l|}{ Rhodocyclus } \\
\hline \multicolumn{5}{|l|}{ Rhodococcus } & AF502232 \\
\hline $\mathrm{B} 16-\mathrm{C}$ & 722 & DQ191245 & 86.1 & Uncultured bacterium clone BA149 & AF323777 \\
\hline \multicolumn{6}{|l|}{ Nitrospira } \\
\hline W17 - C & 658 & DQ238266 & 85.6 & Uncultured bacterium clone SHA-104 & AJ306760 \\
\hline D11 - C & 675 & DQ238272 & 89.5 & Uncultured bacterium clone TTA_B6 & AY297966 \\
\hline $\mathrm{D} 12-\mathrm{C}$ & 668 & DQ238273 & 99.7 & Uncultured bacterium mle1-42 & AF280863 \\
\hline \multicolumn{6}{|l|}{ Uncultured } \\
\hline $\mathrm{W} 18-\mathrm{C}$ & 1069 & DQ238245 & 92.3 & Uncultured bacterium clone BSA2B-20 & AB175392 \\
\hline $\mathrm{B} 20-\mathrm{C}$ & 972 & DQ238252 & 63.1 & Uncultured bacterium clone W31 & AY770971 \\
\hline PL15 - C & 857 & DQ238257 & 66.8 & Uncultured bacterium & AB195900 \\
\hline
\end{tabular}

${ }^{\mathrm{a}} \mathrm{W}=\mathrm{UASB}$ granules used to treat winery wastewater; $\mathrm{B}=$ UASB granules used to treat brewery wastewater; $\mathrm{D}=\mathrm{UASB}$ granules used to treat distillery wastewater; $\mathrm{PL}=\mathrm{UASB}$ granules used to treat peach-lye canning wastewater.

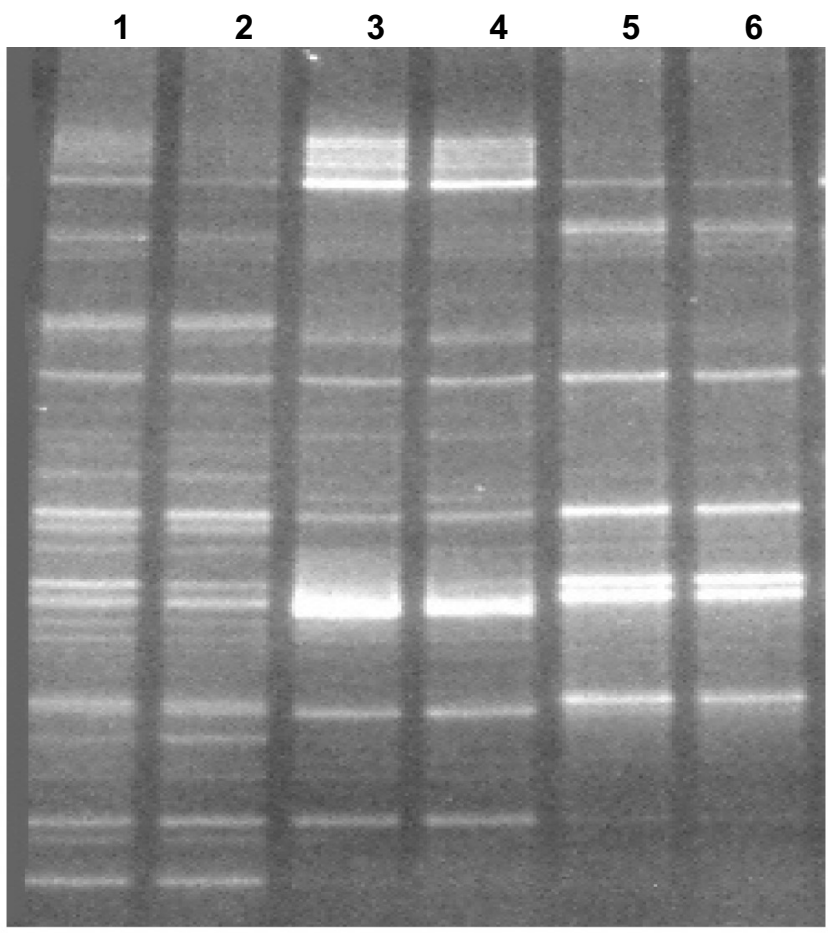

FIGURE 1A

PCR-based DGGE fingerprints of granules from UASB bioreactors used to treat winery wastewater ( 1 and 2$)$, distillery wastewater ( 3 and 4$)$ and brewery wastewater (5 and 6). The identical profiles correspond to two independent DNA extractions.

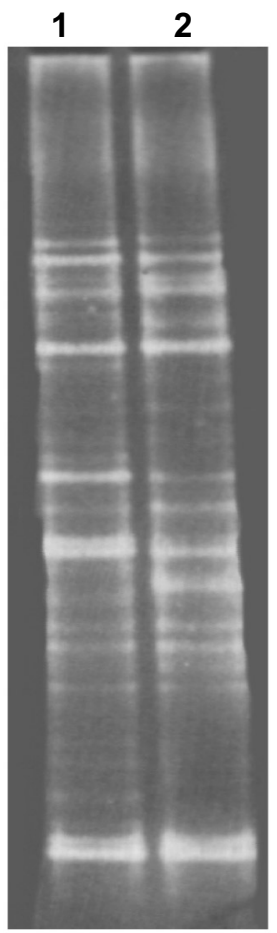

FIGURE 1B

PCR-based DGGE fingerprints of granules from a UASB bioreactor treating peach-lye canning wastewater ( 1 and 2). The identical profiles correspond to two independent DNA extractions. 


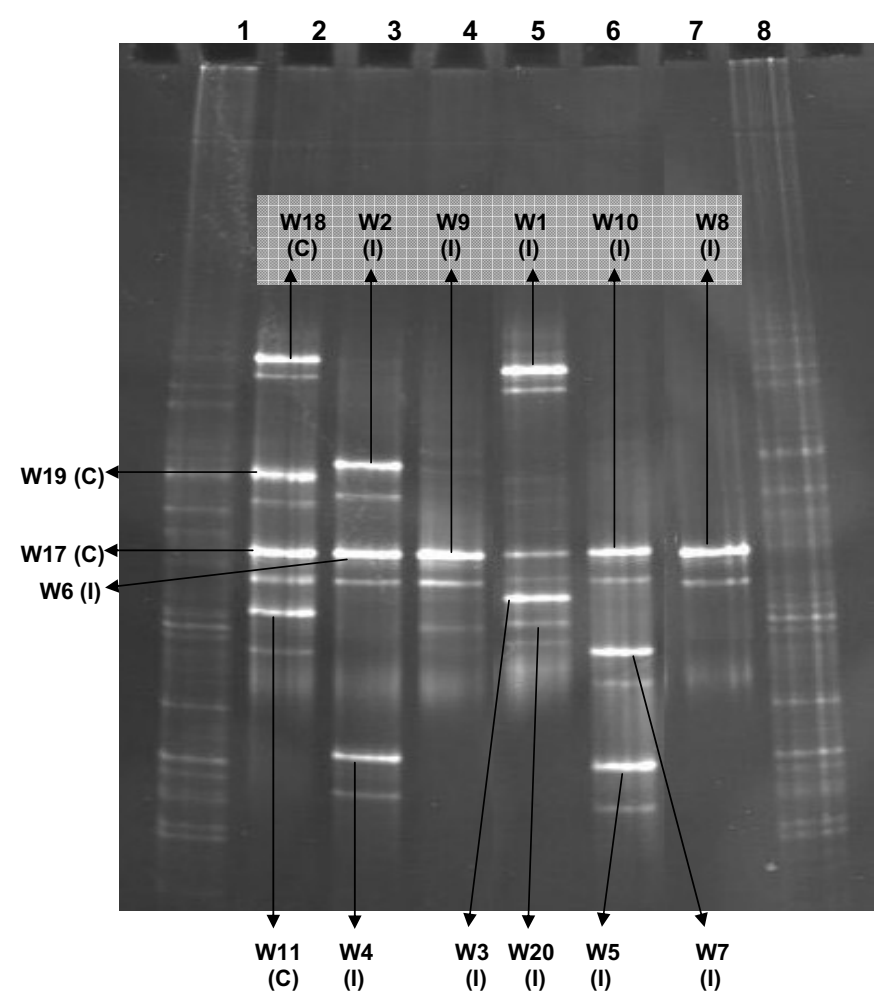

FIGURE 2

Single PCR-based DGGE bands from the cloned inserts (C) and isolates (I) obtained for the winery granules. Lanes $1 \& 8$ : fingerprints of the winery granules that can be used to correlate against the single bands; Lane 2: bands W11, 17, 18 \& 19; Lane 3: W2, 4 \& 6; Lane 4: W9; Lane 5: W1, 3 \& 20; Lane 6: W5, 7 \& 10; and Lane 7: W8.

found to be closely related to B. pumilus, supported by a $99.6 \%$ sequence similarity. Bands D3 and W2 showed a 99.8\% sequence similarity to a Bacillus sp. (Accession number AJ315065) and B. megaterium, respectively. Band W1 was found to be closely related to B. pycnus and band B7 was identified as B. fusiformis, supported by a $100 \%$ sequence similarity, while B12 was found to be closely related to B. sphaericus. The bands W20, D2, D5 and PL6 were all closely related to B. subtilis.

It is generally accepted that most of the bacteria that can survive and be metabolically active in bioreactors are anaerobes, but the aerobic and facultative anaerobic bacteria, such as Bacillus species, still form a significant and constant part of the total bioreactor population. Species of Bacillus are metabolically active during the anaerobic digestion process and can degrade different types of organic compounds, such as proteins, cellulose, starch or lipids (Gerardi, 2003). The presence of Bacillus spp. in a bioreactor may also play a role in the formation of immobilised microbial populations or facilitate their clumping because of their adhesion ability (Petruccioli et al., 2000; Gerardi, 2003). Noeth et al. (1988) isolated B. pumilus, B. subtilis, B. megaterium and B. sphaericus from an anaerobic, fixed-bed bioreactor. They ascribed the growth of the bacilli to sufficient oxygen in the bioreactor that was probably introduced by the substrate. Bacillus coagulans and B. sphaericus were also identified from a laboratory-scale UASB bioreactor (Thierry et al., 2004).

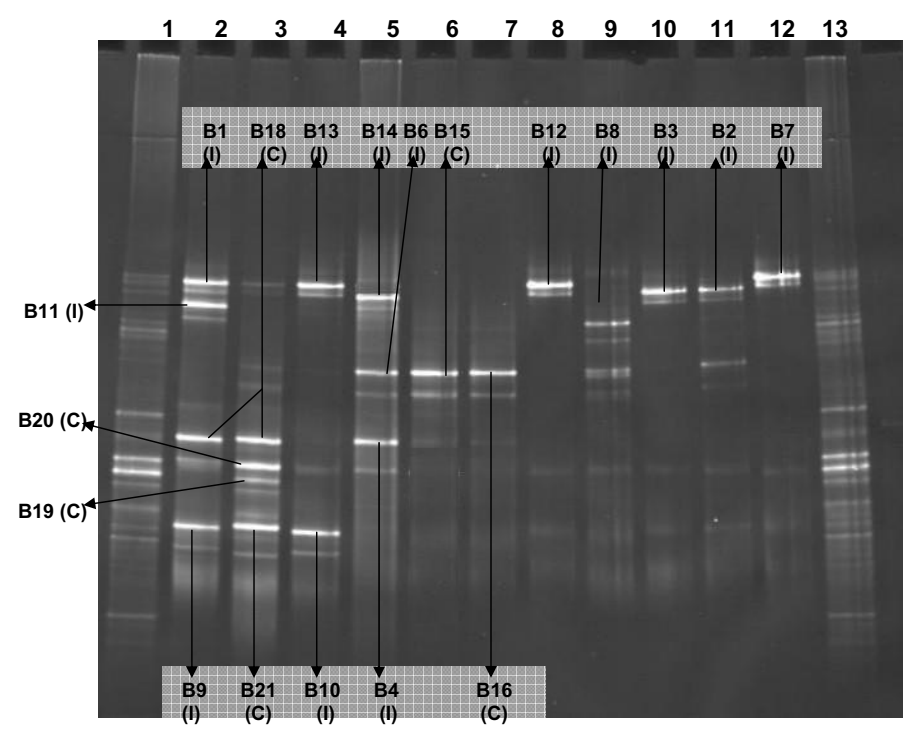

FIGURE 3

Single PCR-based DGGE bands from the cloned inserts (C) and isolates (I) obtained for the brewery granules. Lanes $1 \& 13$ : fingerprints of the brewery granules that can be used to correlate against the single bands; Lane 2: bands B1, 5, 9 \& 11; Lane 3: B18, 19, 20 \& 21; Lane 4: B10 \& 13; Lane 5: B4, 6 \& 14; Lane 6: B15; Lane 7: B16; Lane 8: B12; Lane 9: B8; Lane 10: B3; Lane 11: B2; and Lane 12: B7.

\section{Pseudomonas:}

Fourteen members of the genus Pseudomonas were found as part of the population of the four different UASB granules (Table 1). Nine Pseudomonas species were present in the peach-lye canning granules, four in the distillery granules and one was isolated from the brewery granules. Band B4, from the brewery granules, showed a $99.9 \%$ sequence similarity to Brevundimonas bullata, while band PL11 was found to be closely related to an uncultured gamma Proteobacterium (Li et al., 1999). Band PL19 was found to be closely related to an uncultured bacterium previously isolated from wetland sediments (Accession number AY216460). Band PL5 was closely related to P. fluorescens, a potential phenol-degrading bacterium (Heinaru et al., 2000), and band PL17 showed a sequence similarity of $99.3 \%$ to a Pseudomonas sp. (Accession number AY014806). PL14 was closely related to $P$. veronii, PL22 to $P$. viridiflava and band PL20 was closely related to $P$. putida. The distillery band D13 was closely related to a Pseudomonas sp. (Accession number AY014826), while D4 was found to be closely related to a sulphide-oxidising bacterium, previously isolated from an environmental sample (Accession number AF393509). Bands D6 and PL8 were found to be closely related to these Pseudomonas spp. (Accession numbers AF438148 and AF521651, respectively), and PL1 was closely related to $P$. fluorescens. Band D10 was found to be closely related to Burkholderia pyrrocina. 


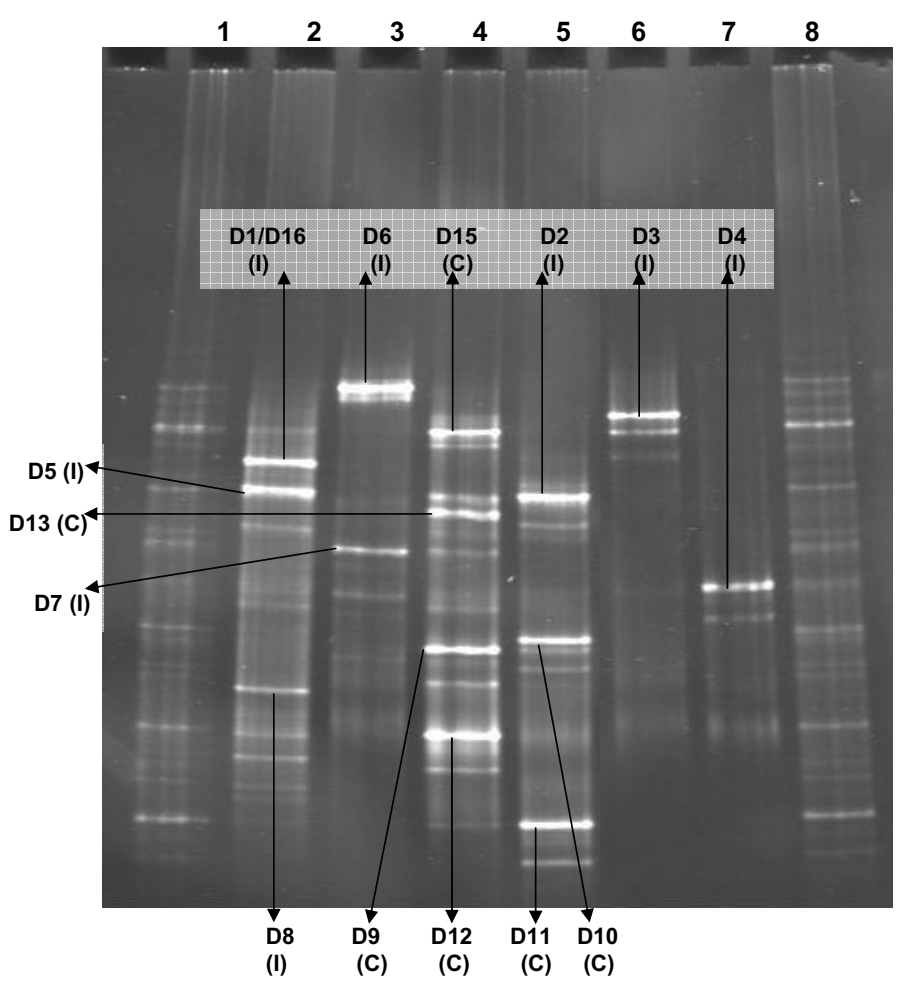

FIGURE 4

Single PCR-based DGGE bands from the cloned inserts (C) and isolates (I) obtained for the distillery granules. Lanes $1 \& 8$ : fingerprints of the distillery granules that can be used to correlate against the single bands; Lane 2: bands D1, 5, 8, 16; Lane 3: D6 \& 7; Lane 4: D9, 12, 13 \& 15; Lane 5: D2, 10 \& 11; Lane 6: D3; and Lane 7: D4.

Several members of the Pseudomonas are known for their ability to degrade aromatic compounds and to produce exo-polysaccharides. This ability might explain why Pseudomonas may play an important role in granulation (Petruccioli et al., 2000). Pseudomonas stutzeri, P. aeruginosa and P. putida have been isolated from UASB bioreactors in the past (De Haast and Britz, 1986; Muthumbi et al., 2001; Pereira et al., 2002; Thierry et al., 2004). Pseudomonas was identified from the brewery, distillery and peach-lye canning granules, but since most of these bacteria were identified from the peach-lye canning granules, it is apparent that the Pseudomonas found the environmental conditions in these granules favourable for growth. A possible explanation for their presence might be that these identified Pseudomonas are halotolerant (Mioni et al., 2003; Lo Nostro et al., 2005) and also could withstand the alkaline environment ( $\mathrm{pH} 8.5$ ) caused by the lye in the wastewater (Sigge et al., 2001). Although Pseudomonas is not classified as alkalophiles, it seems that these identified Pseudomonas was able to metabolise and grow in more alkaline environments.

\section{Bacteroides:}

Four Bacteroides species were identified from the UASB granules that were analysed (Table 1) and two were present in the distillery granules, one in the winery granules and one in the peachlye canning granules. Comparative analysis of the sequences retrieved from GenBank show that band D9 showed the highest

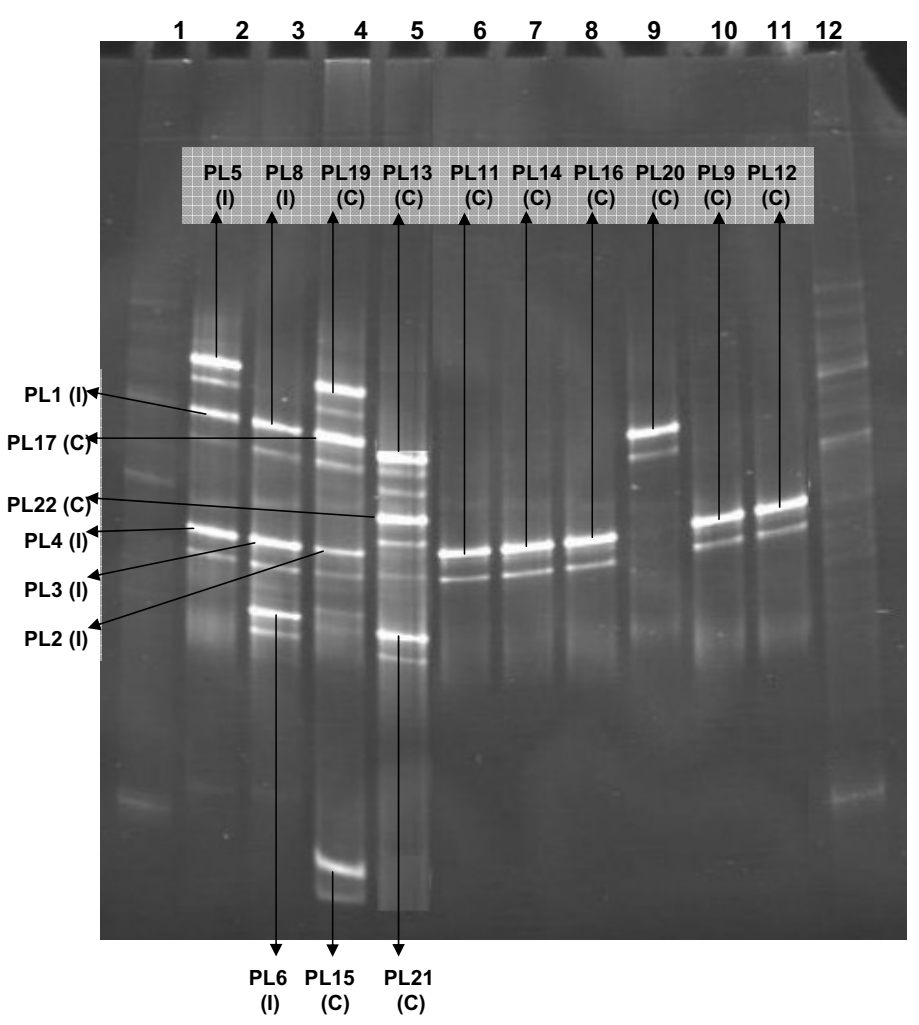

FIGURE 5

Single PCR-based DGGE bands from the cloned inserts (C) and isolates (I) obtained for the peach-lye canning granules that can be used to correlate against the single bands. Lanes $1 \& 12$ : fingerprints of the peach-lye canning granules; Lane 2: bands PL1, 4 \& 5; Lane 3: PL3, 6 \& 8; Lane 4: PL2, 15, 17 \& 19; Lane 5: PL13, 21 \& 22; Lane 6: PL11; Lane 7: PL14; Lane 8: PL16; Lane 9: PL20; Lane 10: PL9; and Lane 11: PL12

sequence similarity (99.8\%) to an uncultured bacterium (Accession number AJ488099). The DGGE band PL16 was shown to be closely related to an uncultured Bacteroidetes bacterium (Accession number AF507859), while the bands W19 and D15 were found to be closely related to an uncultured bacterium previously isolated from environmental samples (Accession number AJ488088).

Gram-negative Bacteroides spp. are acidogenic, anaerobic bacteria (Krieg and Holt, 1984). They can metabolise carbohydrates and peptone to form acetate, lactate, formate or propionate. Members of this genus have been isolated from sewage (Krieg and Holt, 1984), anaerobic bioreactors (Joubert and Britz, 1987; McHugh and O'Flaherty, 2004) and activated sludge (Liu et al., 2005), and include the species B. fragilis, B. distasonis, B. uniformis, B. splanchnicus and B. forsythus.

\section{Enterococcus:}

Three Enterococcus species were isolated from the brewery granules (see Table 1). Band B1 showed a $96.8 \%$ sequence similarity to an uncultured bacterium closely related to the genus Enterococcus (Leser et al., 2002), while bands B11 and B13 represent species that are closely related to Enterococcus sp. (98.1\% sequence similarity) (Chee-Sanford et al., 2001) and E. durans (98.1\% sequence similarity) (Collins et al., 1984) respectively.

Enterococcus is Gram-positive, facultatively anaerobic and ferments carbohydrates to mainly form lactic acid. Enterococcus 


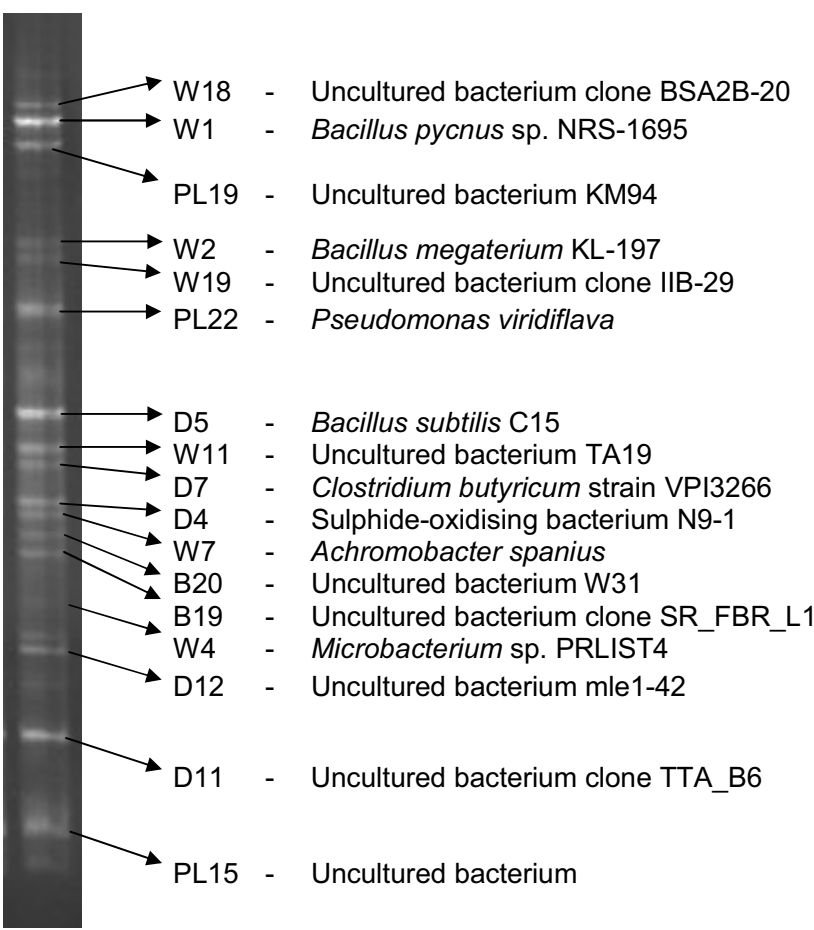

FIGURE 6

DGGE marker constructed from the different bacteria present in the UASB granules that were used to treat winery, brewery, distillery and peach-lye canning wastewaters.

durans, E. avium and E. faecium were isolated from raw baker's yeast effluent (Van der Merwe and Britz, 1994). Chan et al. (2001) studied the microbial community of granular sludge for treating brewery wastewater, but did not identify any Enterococcus species.

\section{Alcaligenes:}

Two species of this genus were identified from the brewery granules and one from the winery granules (Table 1). Band B2 showed a $93.6 \%$ sequence similarity to an uncultured bacterium (Accession number AY214198) related to the genus Alcaligenes. Band B3 showed a $99.8 \%$ sequence similarity to A. faecalis. Alcaligenes spp. can utilise a variety of organic acids and amino acids as carbon sources and certain strains are also capable of anaerobic respiration in the presence of nitrate or nitrite, although A. faecalis can only reduce nitrite (Krieg and Holt, 1984). Alcaligenes faecalis has also previously been isolated from bioreactors (De Haast and Britz, 1986) and the presence of this bacterium was ascribed to the sewage sludge used as inoculum at the start-up of the bioreactor.

Winery band W7 was found to be closely related to Achromobacter spanius, supported by a $99.8 \%$ sequence similarity. Coenye et al. (2003) found that Achromobacter spanius resembled Alcaligenes faecalis phenotypically, but protein and fatty acid analyses showed it to be distinct to Achromobacter. Achromobacter spp. can reduce nitrate and metabolise gluconate, acetate, propionate, butyrate, iso-butyrate and succinate during acetogenesis (Coenye et al., 2003). It may be that the winery granules in this study favoured the growth of Achromobacter, and that the brewery granules favoured the growth of Alcaligenes.

\section{Clostridium:}

Two Clostridium species were isolated, only from the distillery granules (Table 1). Band D7 was found to be closely related to C. butyricum and band $\mathrm{D} 8$ to $C$. bifermentans. Clostridia produce organic acids and alcohols from carbohydrates or peptones (Sneath et al., 1986) and are regarded as acidogenic or homoacetogenic bacteria in anaerobic bioreactors. Clostridium bifermentans was previously isolated from oil mill wastewater (Chamkha et al., 2001) and C. butyricum was a prevalent hydrolytic bacterium in an anaerobic bioreactor treating cheese whey (Chartrain and Zeikus, 1986). Distillery granules favoured the growth of species belonging to the genus Clostridium. This can possibly be ascribed to a favourable redox potential for the development and growth of Clostridia.

\section{Shewanella:}

In this study, band W8 was isolated from the winery granules and band B8 from the brewery granules (Table 1), and they were found to be part of the genus Shewanella. Band W8 showed a $99.5 \%$ and band B8 a $91.2 \%$ sequence similarity to Shewanella putrefaciens. All Shewanella species are Gram-negative and can reduce nitrate to nitrite. Shewanella putrefaciens can reduce trimethylamine $\mathrm{N}$-oxide and sulphur and can produce hydrogen sulphate from thiosulphate (Venkateswaran et al., 1999).

\section{Microbacterium:}

Two Microbacterium species were isolated, only from the winery granules (Table 1). Band W4 was found to be closely related to a Microbacterium sp. (Accession number Y15325), supported by a 99.5\% sequence similarity, and band W5 was identified as M. oxydans (100\% sequence similarity). Microbacterium oxydans can produce acid from glucose, fructose, galactose, mannose, sucrose, maltose, mannitol, glycerol, salicin and dextrin (Schumann et al., 1999). Therefore, the bands W4 and W5 formed part of the acidogenic population in the winery granules.

\section{Leuconostoc:}

One Leuconostoc sp. was isolated from the brewery granules (Table 1). Band B14 was found to be related to an uncultured Leuconostoc sp. (Accession number AF335916), supported by a sequence similarity of $85.1 \%$. This Leuconostoc sp. showed a $99.8 \%$ sequence similarity to Leuc. mesenteroides and it may be possible that B14 is related to Leuc. mesenteroides.

Leuconostoc species are Gram-positive, facultative anaerobes and growth is dependent on the presence of amino acids and fermentable carbohydrates, such as glucose (Sneath et al., 1986). Chartrain and Zeikus (1986) found that Leuc. mesenteroides formed part of the hydrolytic bacteria in an anaerobic bioreactor, making band B14 a member of the acidogenic bacteria in the brewery granules.

\section{Sulfurospirillum:}

Two Sulfurospirillum species were cloned, only from the peachlye canning granules (Table 1). Band PL12 showed a 98.9\% sequence similarity to S. arsenophilum (Stolz et al., 1999) and band PL13 showed a $98.1 \%$ sequence similarity to $S$. halorespirans. Lactate, pyruvate and fumarate can be used by $S$. arsenophilum and $S$. halorespirans as electron donors, but when acetate is used as the carbon source, hydrogen and formate serve as the electron donors (Luijten et al., 2003). 


\section{Acidaminococcus:}

Two uncultured species, related to the genus Acidaminococcus, were identified from the peach-lye canning granules (Table 1). Band PL9 showed a 91.8\% sequence similarity to an unidentified eubacterium (Accession number U81750), which was found to be related to Acidaminococcus fermentans, previously found in anaerobic bioreactors (Godon et al., 1997) and paper mill wastewater (Roest et al., 2005). Band PL21 showed a 94.8\% sequence similarity to an uncultured bacterium (Accession number AY231317) previously detected in an anaerobic bioreactor, which showed a $92 \%$ sequence similarity to A. fermentans.

\section{Vibrio:}

Band B9 showed a $99.9 \%$ sequence similarity to Vibrio parahaemolyticus (Table 1). Vibrio parahaemolyticus has a fermentative metabolism (Krieg and Holt, 1984), thus it may be possible that band B9 was part of the acidogenic bacteria in the brewery granules.

\section{Aeromonas:}

Band B10 showed a $96.2 \%$ sequence similarity to Aeromonas salmonicida (Table 1). Aeromonas has been isolated from winery wastewater (Petruccioli et al., 2000) and raw baker's yeast wastewater (Van der Merwe and Britz, 1994). Species of Aeromonas were found to be partly responsible for phosphorus uptake and release in bioreactors (You et al., 2002; Li et al., 2003).

\section{Syntrophobacter, Rhodocyclus, Rhodococcus, Nitrospira:}

Brewery bands B21, B18, B16, B15 and B19 were all identified as uncultured bacteria. Brewery band B21 showed a 99\% sequence similarity to an uncultured bacterium (Accession number AF482435) (Table 1), previously found in granular sludge, and a sequence similarity of $89.8 \%$ to an uncultured bacterium SJA-172 (Accession number AJ009502). Roest et al. (2005) also identified uncultured bacterium SJA-172 in a UASB bioreactor and suggested that this bacterium might be involved in the oxidation of propionate. Propionate oxidation is an energetically unfavourable reaction and microorganisms involved in the degradation of propionate play a crucial role in the anaerobic degradation process in methanogenic bioreactors. Uncultured bacterium SJA-172 was found to be closely related to Syntrophobacter wolinii. It is, therefore, possible that band B21 and the uncultured bacterium R1p32 may be related to the genus Syntrophobacter.

Band B18 showed a $95.5 \%$ sequence similarity to an uncultured bacterium (Accession number AF502232) previously present in activated sludge with high phosphorus content. This uncultured bacterium was found to be closely related to a species belonging to the genus Rhodocyclus, which was associated with phosphorus removal in sludges (McMahon et al., 2002). This supports the finding that band B18 may be related to the genus Rhodocyclus. The growth rate of Rhodocyclus species can be increased in the presence of complex organic nutrients or even yeast extract (Staley et al., 1989). Since band B18 was found in UASB granules used to treat brewery wastewater, it is possible that these bacteria could have used the yeast cells for their metabolism.

Band B16 showed an $86.1 \%$ sequence similarity to uncultured bacterium clone BA149 previously found in environmental sam- ples (Accession number AF323777). Bacterium clone BA149 was found to show a sequence similarity of $74.1 \%$ to Rhodococcus rhodochrous, which can produce acid from dextrine, ethanol, fructose, glucose and sucrose (Sneath et al., 1986) and may have played an important role during acidogenesis in the brewery granules. Hawari et al. (2000) found that Rhodococcus produced formaldehyde or methanol as end-products during the anaerobic biodegradation of anaerobic sludge.

Band B15 showed an $88.2 \%$ sequence similarity to uncultured bacterium DCE29 (Gu et al., 2004) and B19 showed a 99.8\% sequence similarity to uncultured bacterium SR_FBR_L1 (Kakosen et al., 2004) (Table 1). Gu et al. (2004) reported that the uncultured bacterium DCE29 used hydrogen as an electron donor and could be affiliated with the genus Nitrospira. Uncultured bacterium SR_FBR_L1 was identified as part of a lactate-utilising sulphate-reducing fluidised-bed bioreactor bacterial community (Kakosen et al., 2004).

\section{Synergistes:}

Four uncultured bacteria were identified from the winery and distillery granules and found to be related to the genus Synergistes. These are acidogenic bacteria associated with anaerobic bioreactors and soil (Godon et al., 2005) (Table 1). Band W11 showed a $98.2 \%$ sequence similarity to the uncultured bacterium TA19, previously identified in a UASB bioreactor (Wu et al., 2001) and found to be closely related to Synergistes jonesii. Band D12 showed a $99.7 \%$ sequence similarity to the uncultured bacterium mle1-42, which was found to be present in bioreactors (Lapara et al., 2000; Pereira et al., 2002). Uncultured bacterium mle1-42 formed part of a cluster containing $S$. jonesii (Lapara et al., 2000). Band W17 showed a high sequence similarity of $94.4 \%$ to DGGE band D11, which also showed an $89.5 \%$ sequence similarity to the uncultured bacterium clone TTA_B6. This bacterium was found to be the second "most dominant" bacteria in an anaerobic reactor (Chen et al., 2004). This organism was closely related to an environmental clone MUG10 (Sekiguchi et al., 1998).

\section{Other uncultured bacteria:}

Band W18 showed a $92.3 \%$ sequence similarity to the uncultured bacterium clone BSA2B-20 (Accession number AB175392). Bands B20 and PL15 showed a sequence similarity of $63.1 \%$ and $66.8 \%$, respectively to an uncultured bacterium clone W31 (Accession number AY770971) and an uncultured bacterium (Accession number AB195900). The sequence similarities of $63.1 \%$ and $66.8 \%$ are low and the identification of these two bacteria is uncertain.

A 200 bp PCR fragment was amplified from each $1.5 \mathrm{~kb}$ PCR fragment from the pure isolates and the cloned inserts, using the primers F341 and R534 (Muyzer et al., 1993). This was done to confirm that each band in the DGGE fingerprints was sequenced and identified. It was observed that many of the DGGE single bands were accompanied at close distance by another band. Such shadow bands also occurred with the cloned sequences. However, similar observations of artifactual 'double bands' have been reported by other researchers (Janse et al., 2004). These shadow bands could be formed during PCR cycling, when secondary products are formed due to prematurely halted elongation. Although Janse et al. (2004) decreased the intensity of the artifactual bands by extending the final elongation step, it did not 
have the same effect in this study. In Figures 2 to 5, the single bands obtained for the winery, brewery, distillery and peach-lye canning granules can be observed. In Figure 2, more than one PCR product was loaded in lanes 1, 2, 5 and 6 specifically. The separate PCR products $(2 \mu \mathrm{l}$ of each product) were loaded in one well in order to accommodate all the bands of the winery granules in one gel. The same was done for the brewery, distillery and peach-lye canning granules. The identified microorganisms where then visually correlated to the corresponding DGGE band in the profiles to enable the construction of a DGGE marker.

\section{DGGE marker}

The developed DGGE marker was constructed using selected DGGE bands from the profiles obtained for the winery, brewery, distillery and peach-lye canning effluent granules (Figure 6). This marker represents the bacteria that were most present in the four different granules used in this study, and can be of great value for the possible identification or indication of members of the microbial consortium in UASB bioreactors.

Since it is an extremely time-consuming process to identify microorganisms, especially those that are not readily cultured, the use of the DGGE marker can be of great assistance to provide a quick method to verify the presence of these microorganisms where each bacterium has a specific role to play during anaerobic digestion. Knowledge of the composition of the microbial consortium can be of great value during the start-up of a new bioreactor, and the marker can be used as a reference to monitor the various microorganisms during their adaptation period in a new bioreactor or a bioreactor treating a new type of wastewater.

\section{CONCLUSIONS}

During the past decade, advances in molecular biology have provided better insight into the structure of complex microbial communities. In this study, PCR-based DGGE proved useful to fingerprint the various UASB granules. It is evident from the results obtained that the use of culture-independent molecular techniques is essential, since a total of $35 \%$ of the identified bacteria were unculturable bacteria. This study therefore clearly shows the value of integrated culture-dependent and culture-independent research.

The different bacteria that were isolated and identified from the different granules emphasise the fact that the composition of each type of wastewater has a major impact on the microbial species present in the granules. Fingerprinting and identification of the complex microbial bacterial community in UASB granules may lead to a better understanding of the influence that the treatment of various wastewaters may have on the structure of the different populations present in the UASB granules. A better understanding of the diversity of bacteria in different UASB granules can improve the stability of the anaerobic process and the performance of the bioreactor. The metabolic activity of the different groups of bacteria plays a major role during anaerobic digestion and, if the bacteria are identified, it is possible that tailor-made granules could be used to enhance bioreactor process stability. Tailor-made granules may also be used to reduce the start-up period. The survival of these incorporated microorganisms used to enhance bioreactor efficiency may be monitored by using the DGGE marker that was constructed in this study.

A major advantage of this DGGE marker is that it could be complemented by additional DGGE bands found in UASB biore- actors. The DGGE marker can also be used to assist in the monitoring of selected species during bio-augmentation or enrichment of granules for the treatment of specific wastewaters. The DGGE marker has to be used in combination with sequence analysis when analysing new granule batches. It is possible that some overlapping of the microorganisms can take place in the DGGE profiles under certain conditions.

The data obtained in this study should be of value in the future identification of microbial communities present in anaerobic digestion studies, as well as for the process optimisation of UASB bioreactors.

\section{LITERATURE CITED}

Altschul, S.F., Gish, W., Miller, W., Myers, E.W. \& Lipman, D.J., 1990. Basic local alignment search tool. J. Mol. Biol. 215, 403-410.

Batstone, D.J., Keller, J., Angelidaki, I., Kalyuzhnyi, S.V., Pavlostathis, S.G., Rozzi, A., Sanders, W.T.M., Siegrist, H. \& Vavilin, V.A., 2002. In: Hammett, J. \& Buzzard, L. (eds). Anaerobic Digestion Model No. 1 (ADM1), IWA Task Group for Mathematical Modelling of Anaerobic Digestion Processes. IWA Publishing, London, pp. $3-32$.

Casserly, C. \& Erijman, L., 2003. Molecular monitoring of microbial diversity in an UASB reactor. Int. Biodeterior. Biodegrad. 52, 7-12.

Chamkha, M., Patel, B.K.C., Garcia, J-L. \& Labat, M., 2001. Isolation of Clostridium bifermentans from oil mill wastewaters converting cinnamic acid to 3-phenylpropionic acid and emendation of the species. Anaerobe 7, 189-197.

Chan, O.-C., Liu, W.T. \& Fang, H.H.P., 2001. Study of microbial community of brewery-treating granular sludge by denaturing gradient gel electrophoresis of 16S rRNA gene. Wat. Sci. Tech. 43, 77-82.

Chartrain, M. \& Zeikus, J.G., 1986. Microbial ecophysiology of whey biomethanation: Characterisation of bacterial trophic populations and prevalent species in continuous culture. Appl. Environ. Microbiol. 51, 188-196.

Chee-Sanford, J.C., Aminov, R.I., Krapac, I.J., Garrigues-Jeanjean, N. \& Mackie, R.I., 2001. Occurrence and diversity of tetracycline resistance genes in lagoons and groundwater underlying two swine production facilities. Appl. Environ. Microbiol. 67, 1494-1502.

Chen, C.-L., Macarie, H., Ramirez, I., Olmos, A., Ong, S.L., Monroy, O. \& Liu, W.-T., 2004. Microbial community structure in a thermophilic anaerobic hybrid reactor degrading terephthalate. Microbiol. 150, 3429-3440.

Coenye, T., Vancanneyt, M., Falsen, E., Swings, J. \& Vandamme, P., 2003. Achromobacter insolitus sp. nov. and Achromobacter spanius sp. nov., from human clinical samples. Int. J. Sys. Evol. Microbiol. 53, 1819-1824.

Collins, M.D., Jones, D., Farrow, J.A.E., Klipper-Bälz, R. \& Schleifer, K.H., 1984. Enterococcus avium nom. rev., comb. nov.; E. casseliflavus nom. rev., comb. nov.; E. durans nom. rev., comb. nov.; E. gallinarum comb. nov.; and $E$. malodoratus sp. nov. Int. J. Sys. Bacteriol. 34, 220-223.

De Haast, J. \& Britz, T.J., 1986. Characterization of aerobic and facultative anaerobic bacteria from the liquid phase of an anaerobic fixed-bed digester treating a cheese whey substrate. Microb. Ecol. 12, 173-179.

Felske, A., Rheims, H., Wolterink, A., Stackebrandt, E. \& Akkermans, A.D.L., 1997. Ribosome analysis reveals prominent activity of an uncultured member of the class Acinetobacteria in grassland soils. Microbiol. 143, 2983-2989.

Gerardi, M.H., 2003. The Microbiology of Anaerobic Bioreactors. John Wiley \& Sons, New Jersey.

Godon, J.J., Morinière, J., Moletta, M., Gaillac, M., Bru, V. \& Delgènes, J-P., 2005. Rarity associated with specific ecological niches in the bacterial world: The 'Synergistes' example. Environ. Microbiol. 7, 213-224.

Godon, J.J., Zumstein, E., Dabert, P., Habouzit, F. \& Moletta, R., 1997. Molecular microbial diversity of an anaerobic digester as determined by small-subunit rDNA sequence analysis. Appl. Environ. Microbiol. 63, 2802-2813. 
Gu, A.Z., Hedlund, B.P., Staley, J.T., Strand, S.E. \& Stensel, H.D., 2004. Analysis and comparison of the microbial community structures of two enrichment cultures capable of reductively dechlorinating TCE and cis-DCE. Environ. Microbiol. 6, 45-54.

Hawari, J., Halasz, A., Sheremata, T., Beaudet, S., Groom, C., Paquet, L., Rhofir, C., Ampleman, G. \& Thiboutot, S., 2000. Characterisation of metabolites during biodegradation of hexahydro-1,3,5-trinitro-1,3,5-triazine (RDX) with municipal anaerobic sludge. Appl. Environ. Microbiol. 66, 2652-2657.

Heinaru, E., Truu, J., Stottmeister, U. \& Heinaru, A., 2000. Three types of phenol and p-cresol catabolism in phenol- and p-cresol-degrading bacteria isolated from river water continuously polluted with phenolic compounds. FEMS Microbiol. Ecol. 31, 195-205.

Janse, I., Bok, J. \& Zwart, G., 2004. A simple remedy against artifactual double bands in denaturing gradient gel electrophoresis. J Microbiol Meth. 57, 279-281.

Joubert, W.A. \& Britz, T.J., 1987. Characterisation of aerobic, facultative anaerobic, and anaerobic bacteria in an acidogenic phase reactor and their metabolic formation. Microb. Ecol. 13, 159-168

Kakosen, A.H., Plumb, J.J., Franzmann, P.D. \& Puhakka, J.A., 2004. Simple organic electron donors support diverse sulphate-reducing communities in fluidised-bed reactors treating acidic metal- and sulphate-containing wastewater. FEMS Microbiol. Ecol. 47, 279-289.

Keyser, M., Witthuhn, R.C., Coetzee, M.P.A. \& Britz, T.J., 2006. PCR-based DGGE fingerprinting and identification of methanogens detected in three different types of UASB granules. Sys. Appl. Microbiol. 29, 77-84.

Krieg, N.R. \& Holt, J.G., 1984. Gram-negative aerobic rods and cocci. In: Bergey's Manual of Systematic Bacteriology, Vol. 1. Williams \& Wilkins, Baltimore.

Kumar, S., Tamura, K., Jakobsen, I.B. \& Nei, M., 2001. MEGA 2: Molecular evolutionary analysis software. Bioinfor. 17, 1244-1245.

Lapara, T.M., Nakatsu, C.H., Pantea, L. \& Alleman, J.E., 2000. Phylogenetic analysis of bacterial communities in mesophilic and thermophilic bioreactors treating pharmaceutical wastewater. Appl. Environ. Microbiol. 66, 3951-3959.

Leser, T.D., Amenuvor, J.Z., Jensen, T.K., Lindecrona, R.H., Boye, M. \& Moller, K., 2002. Culture-independent analysis of gut bacteria: The pig gastrointestinal tract microbiota revisited. Appl. Environ. Microbiol. 68, 673-690.

Li, J., Xing, X.-H. \& Wang, B.-Z., 2003. Characteristics of phosphorus removal from wastewater by biofilm sequencing batch reactor (SBR). Biochem. Eng. J. 16, 279-285.

Li, L., Kato, C. \& Horikoshi, K., 1999. Bacterial diversity in deep-sea sediments from different depths. Biodiver. Conserv. 8, 659-677.

Liu, Y., Zhang, T. \& Fang, H.H.P., 2005. Microbial community analysis and performance of a phosphate-removing activated sludge. Biores. Technol. 96, 12051214.

Lo Nostro, P., Ninham, B.W., Lo Nostro, A., Pesavento, G., Fratoni, L. \& Baglioni, P., 2005. Specific ion effects on the growth rates of Staphylococcus aureus and Pseudomonas aeruginosa. Phys. Biol. 2, 1-7.

Luijten, M.L.G.C., De Weert, J., Smidt, H., Boschker, H.T.S., De Vos, W.M., Schraa, G. \& Stams, A.J.M., 2003. Description of Sulfurospirillum halorespirans sp. nov., an anaerobic, tetrachloroethene-respiring bacterium, and transfer of Dehalospirillum multivorans to the genus Sulfurospirillum as Sulfurospirillum multivorans comb. nov. Int. J. Sys. Evol. Microbiol. 53, 787-793.

McHugh, S. \& O'Flaherty, V., 2004. Microbial community structure and dynamics during long-term anaerobic biological treatment of whey-based wastewaters at psychrophilic temperature. In: Proc. 10th Anaerobic Digestion Conference, Montréal, Canada. pp. $1554-1557$.

McMahon, K.D., Dojka, M.A., Pace, N.R., Jenkins, D. \& Keasling, J.D., 2002. Polyphosphate kinase from activated sludge performing enhanced biological phosphorus removal. Appl. Environ. Microbiol. 68, 4971-4978.

Mioni, C.E., Howard, A.M., DeBruyn, J.M., Bright, N.G., Twiss, M.R., Applegate, B.M. \& Wilhelm, S.W., 2003. Characterisation and field trials of a bioluminescent bacterial reporter of iron bioavailability. Mar. Chem. 83, 31-46.

Muthumbi, W., Boon, N., Boterdaele, R., De Vreese, I., Top, E.M. \& Verstraete, W., 2001. Microbial sulfate reduction with acetate: process performance and composition of the bacterial communities in the reactor at different salinity levels. Appl. Microbiol. Biotechnol. 55, 787-793.

Muyzer, G., De Waal, E.C. \& Uitterlinden, A.G., 1993. Profiling of complex microbial populations by denaturing gradient gel electrophoresis analysis of polymerase chain reaction-amplified genes coding for $16 \mathrm{~S}$ rRNA. Appl. Environ. Microbiol. 59, 695-700.

Noeth, C., Britz, T.J. \& Joubert, W.A., 1988. The isolation and characterization of the aerobic endospore-forming bacteria present in the liquid phase of an anaerobic fixed-bed digester, while treating a petrochemical effluent. Microb. Ecol. 16, 233-240.

Pereira, M.A., Roest, K., Stams, A.J.M., Mota, M., Alves, M. \& Akkermans, A.D.L., 2002. Molecular monitoring of microbial diversity in expanded granular sludge bed (EGSB) reactors treating oleic acid. FEMS Microbiol. Ecol. 41, 95103.

Petruccioli, M., Duarte, J.C. \& Federich, F., 2000. High-rate aerobic treatment of winery wastewater using bioreactors with free and immobilized activated sludge. J. Biosci. Bioeng. 90, 381-386.

Roest, K., Heilig, H.G.H.J., Smidt, H., De Vos, W.M., Stams, A.J.M. \& Akkermans, A.D.L., 2005. Community analysis of a full-scale anaerobic bioreactor treating paper mill wastewater. Sys. Appl. Microbiol. 28, 175-185.

Schumann, P., Rainey, F.A., Burghardt, J., Stackebrandt, E. \& Weiss, N., 1999. Reclassification of Brevibacterium oxydans (Chatelain and Second 1966) as Microbacterium oxydans comb. nov. Int. J. Sys. Bacteriol. 49, 175-177.

Sekiguchi, Y., Kagamata, Y., Syutsubo, K., Ohashi, A., Harada, H. \& Nakamura, K., 1998. Phylogenetic diversity of mesophilic and thermophilic granular sludges determined by 16S rRNA gene analysis. Microbiol. 144, 2655-2665.

Sigge, G.O., Britz, T.J., Fourie, P.C., Barnardt, C.A. \& Strydom, R., 2001. Use of ozone and hydrogen peroxide in the post-treatment of UASB treated alkaline fruit cannery effluent. Wat. Sci. Technol. 44, 69-74.

Sneath, P.H.A., Mair, N.S., Sharpe, M.E. \& Holt, J.G., 1986. Bergey's Manual of Systematic Bacteriology, Vol. 2. Williams \& Wilkins, Baltimore.

Staley, J.T., Bryant, M.P., Pfennig, N. \& Holt, J.G., 1989. Bergey's Manual of Systematic Bacteriology, Vol. 3. Williams \& Wilkins, Baltimore.

Stolz, J.F., Ellis, D.J., Blum, J.S., Ahmann, D., Lovley, D.R. \& Oremland, R.S., 1999. Sulfurospirillum barsenii sp. nov. and Sulfurospirillum arsenophilum sp. nov., new members of the Sulfurospirillum clade of the Proteabacteria. Int. J. Sys. Bacteriol. 49, 1177-1180.

Thierry, S., Mariaca, P., Raminez, F. \& Macarie, H., 2004. Strict aerobes, autochthonous or passenger microorganisms in anaerobic reactors? In: Proc. 10th Anaerobic Digestion Conference, Montréal, Canada. pp. 167 - 173.

Trnovec, W. \& Britz, TJ., 1998. Influence of organic loading rate and hydraulic retention time on the efficiency of a UASB bioreactor treating a canning factory effluent. Water SA 24, 147-152.

Van Andel, J.G. \& Breure, A.M., 1984. Anaerobic wastewater treatment. Trends Biotechnol. 2, 16-20.

Van der Merwe, M. \& Britz, T.J., 1994. Characterisation and numerical analysis of the microbial community in raw baker's yeast factory effluent. Water SA 20 , $161-168$

Van Elsas, J.D., Mäntynen, V. \& Wolters, A.C., 1997. Soil DNA extraction and assessment of the fate of Mycobacterium chlorophenolicum strain PCP-1 in different soils by $16 \mathrm{~S}$ ribosomal RNA gene sequence based most probable number PCR and immunofluorescence. Biol. Fert. Soil. 24, 188-195.

Venkateswaran, K., Moser, D.P., Dollhopf, M.E., Lies, D.P., Saffarini, D.A., MacGregor, B.J., Ringelberg, D.B., White, D.C., Nishijima, M., Sano, H., Burghardt, J., Stackebrandt, E. \& Nealson, K.H., 1999. Polyphasic taxonomy of the genus Shewanella and description of Shewanella oneidensis sp. nov. Int. J. Sys. Bacteriol. 49, 705-724.

Wangnai, C., Zeng, R.J. \& Keller, J., 2004. Characterisation of high-rate acidogenesis processes using a titration and off-gas analysis (TOGA) sensor. In: Proc. 10th Anaerobic Digestion Conference, Montréal, Canada. pp. 27 - 32.

Wolmarans, B. \& De Villiers, G.H., 2002. Start-up of a UASB effluent treatment plant on distillery wastewater. Water SA 28, 63-68.

Wu, J.-H., Liu, W.-T., Tseng, I.-C. \& Cheng, S.-S., 2001. Characterisation of microbial consortia in a terephthalate-degrading anaerobic granular sludge system. Microbiol. 147, 373-382.

You, S.J., Hsu, C.L. \& Ouyang, C.F., 2002. Identification of the microbial diversity of wastewater nutrient removal processes using molecular biotechnology. Biotechnol. Lett. 24, 1361-1366. 